\title{
THE EFFECT OF HUMAN CAPITAL ON ORGANIZATIONAL PERFORMANCE: THE CASE OF SUSTAINABILITY ISSUES IN AN E-COMMERCE FIRM
}

\author{
Patrick Balian *, Assaad Farah ${ }^{* *}$, Udo Braendle ${ }^{* * *}$ \\ * ISEOR Research Center, Jean Moulin Lyon III University, Lyon, France \\ ** School of Business Administration, American University in Dubai, Dubai, UAE \\ *** Corresponding author, School of Business Administration, American University in Dubai, Dubai, UAE \\ Contact details: School of Business Administration, American University in Dubai, Sheikh Zayed Rd, Al Sufouh 2, Dubai, UAE
}

OPEN ACCESS

How to cite this paper: Balian, $P$. Farah, A., \& Braendle, U. (2020). The effect of human capital on organizational performance: The case of sustainability issues in an e-commerce firm. Corporate Governance and Sustainability Review, 4(2), 20-29.

http://doi.org/10.22495/cgsrv4i2p2

Copyright $@ 2020$ The Authors

This work is licensed under a Creative Commons Attribution 4.0 International License (CC BY 4.0). https://creativecommons.org/licens es/by/4.0/

ISSN Online: 2519-898X ISSN Print: 2519-8971

Received: 14.05.2020 Accepted: 07.07.2020

JEL Classification: E22, L81, O34 DOI: $10.22495 /$ cgsrv4i2p2

\begin{abstract}
This paper aims to discuss how developing human capital can have a direct positive effect on operational performance. The case study method is used to address the sustainability issues a Lebanon-based retail e-commerce company is facing. We utilize the socio-economic qualimetrics methodology to discuss the corporate change from within the enterprise at all levels and with the contribution of all the participants in the firm. The focus of the case study is on qualitative, quantitative, and financial aspects through competitiveness enhancement and operational effectiveness metrics. The findings of this intervention research contribute to the literature insofar as enhancing the social capital of a retail e-commerce organization positively impacts its performance.
\end{abstract}

Keywords: Intellectual Capital, Human Capital, Socio-economic, E-commerce Performance

Authors' individual contribution: Conceptualization - P.B., A.F., and U.B.; Methodology - P.B.; Validation - P.B., A.F., and U.B.; Formal Analysis P.B., A.F., and U.B.; Investigation - P.B., A.F., and U.B.; Data Curation P.B.; Writing - Original Draft - P.B., A.F., and U.B.; Writing - Review \& Editing - P.B., A.F., and U.B.; Visualization - P.B.

Declaration of conflicting interests: The Authors declare that there is no conflict of interest.

\section{INTRODUCTION}

E-commerce businesses are facing numerous obstacles in the e-commerce sector today, corporate leadership is intensely concentrated on resources, eliminates routine tasks, and intensifies the usage of technology to achieve operational priorities (Oppong, Yen, \& Merhout, 2005). Consumers require their orders to be fulfilled on schedule, which requires the company to have to have enough inventory in place to accommodate and fulfill requests purchased by the clients. Retail e-commerce has a big inventory on hands which puts a lot of pressure on the cash flow of the company. Therefore, timely inventory management is very necessary and e-commerce firms are constantly using it to bring into lines their consumer satisfaction requirements with their rising demands
(Ranjan, Siddiqui, Thapar, \& Chauhan, 2020). Furthermore, the cost of production, storage, and delivery must be calculated from the point of view of cost-effectiveness, known as "cost of order fulfillment" (Tian, Vakharia, Tan, \& Xu, 2018). The internet and technological innovation have altered the way businesses capture, protect, and handle customer data; therefore, the techniques for content targeting and advertisement have shifted. Such software and process systems have proved to capture valuable user data. E-commerce businesses that effectively incorporate or develop these programs offer strategic benefits in terms of cost, emphasis, and procurement techniques.

While researchers have identified key contributors to the growth of e-commerce firms with a broad variety of online product products (Park, Kim, Funches, \& Foxx, 2012), highly competitive 
marketing pricing (Bruce \& Daly, 2010) and high-quality consumer service capabilities and procedures (Brugnoli, Mangiaracina, \& Perego, 2009), the use of the latest technological logistics strategies (Ghezzi, Mangiaracina, \& Perego, 2012) and excellent norms for return and exchange of products. Efficient communication and control between purchasing departments and suppliers, manufacturing, storage, and transportation providers, a corporation's strategic business plan and competition, and finally customer support and service (Oppong, Yen, \& Merhout, 2005), are the key drivers of the firm's performance.

E-commerce retail firms carry out borderless activities and are facing intense pressure from domestic and foreign e-commerce businesses. These firms will also try to create their own competitive advantage so they can succeed and remain ahead of the market. Business leaders are becoming highly familiar with intangible assets, particularly intellectual capital, in the current competitive corporate environment, due to their significant positive effect on operational success (Edvinsson \& Malone, 1997; Braendle, Farah, \& Balian, 2017). Scholars argue that the development of intellectual capital in this knowledge economy will greatly increase innovation and production (Wang \& Chang, 2005; Youndt \& Snell, 2004). Edvinsson and Malone 1997 identify intellectual capital as operational infrastructure, employee skill sets, experience, and knowledge, as well as client relationships that generate intellectual capital. As regards to the goal of this intervention research, the intervener stressed on only human capital out of three major classifications of the intellectual capital variables: human, structural, and social capital as per the following researchers: Subramaniam and Youndt (2005), Youndt and Snell (2004), Youndt, Subramaniam, and Snell (2004). The intervener concludes that the literature offers blind areas for investigating the effects of human capital on retail e-commerce companies' performance.

This intervention research is performed in a small limited liability company based in Lebanon, which was formed in 2009. As founders and managing directors, the company has two brothers. The enterprise conducts business in the retail e-commerce sector and has two additional members of staff. The organization's products are being sold online around the world. It has established its own online shopping store and is marketing its products through a third-party website (Walmart, Amazon, and eBay).

Therefore, this choice of a company as a sector for intervention research has three folds. Firstly, the corporation activities are in the intervener's interest and expertise arena. The researchers have significant experience in valuing retail e-commerce companies, in integrating and merging purchased companies with the existing acquirer's activities to synchronize all operations. Second, the outcomes of the research should be of immense value to the organization, as this will improve its structure and ensure its longterm survival. Third, the impetus of the intervener to conduct intervention research through applying socio-economic methods as a technique of structural development with quantifiable results in the qualitative, quantitative, and financial arena, with the goal of improving the socio-economic performance of the company through increasing human resources.

In this research, the hypothesis describes the dynamics of intervention analysis and decodes the concept suggested in the empirical review into the systemic framework of the company as follows: "Enhancement of human capital improves retail e-commerce firm's performance". This research question revolves around the topics of "how can the enhancement of human capital help to improve the ecommerce firm's performance?" and "how can the SEAM intervention contribute to the performance enhancement of e-commerce firms?"

The purpose of this research is to add to the literature on human capital, which is an intellectual capital component. This intervention study conducts a combination of qualitative, quantitative, and financial examinations into the effect of human capital on the performance of a Lebanese retail ecommerce sector.

The rest of the paper is organized as follows. Section 2 discussed the research methodology. In Section 3 we review the literature in the field. Section 4 discusses the research results. In Section 5 the results are discussed and we conclude.

\section{LITERATURE REVIEW}

The intervention researcher took from the hypothesis the relative literature which forms the basis for literary discussion and the illustrations of this research.

Many dominant scholars such as Bontis (1996), Brooking (1996), Edvinsson and Malone (1997), Stewart (1997), Youndt Subramaniam, and Snell (2004), Youndt and Snell (2004) developed and shaped significant contributions to the intellectual capital field. Different definitions have been established for intellectual capital, but no specific consensus has been found. Moreover, the beneficial effect on organizational efficiency by enhancing intellectual capital differs from the company's market share, operating profitability, financial ratios, and valuation.

One aspect of intellectual capital is that intellectual capital may be defined as all intangible assets and services, such as know-how, technological expertise and knowledge, manufacturer and consumer relations, internal and external exchange of information, rules, databases, trademarks, organizational structures, manuals, operational processes that are used successfully to create economic value (MacCarthy \& Amoasi-Andoh, 2020). Steward (1997) defined intellectual capital as records, intellectual property, intellectual knowledge, skills, key strategies, consumer relationships, and experience that can be used to make the company richer (Stewart, 1997). In addition, an alternate definition is that intellectual capital constitutes the sum of all knowledge-intelligence companies used for competitive advantage (Subramaniam \& Youndt, 2005). Bontis (2001) and Wang and Chang (2005) argue that the company's principal driver is intellectual capital. In fact, we conclude that the various meanings presented are very similar and address more or less the same ideas but with various terminologies. For the purpose of this research, we have chosen to use the same definition 
of intellectual capital as described by Sullivan and Edvinsson (1996), as it covers all the important components of our research field.

The three-variable categorization of intellectual capital was the key approach defined by pioneering scholars. The variables of intellectual capital are defined as human, structural, and social capital. We will define, describe, and clarify only human capital for the purpose and interest of this research study, in the next section.

Many significant contributions to intellectual capital and its human capital variable haven been performed and developed by a number of prominent authors such as Bontis (1998), Stewart (1997), Edvinsson and Malone (1997)б Youndt and Snell (2004). There is a common understanding among scholars on the general essence of the human capital definition in the context of intellectual capital. They define human capital as the employees' knowledge, know-how, education, training, skills, abilities, and characteristics (Bontis, 1998; Dzinkowski, 2000; Edvinsson \& Malone, 1997; Roos \& Roos, 1997; Stewart, 1997; Bontis, Chua, \& Richardson, 2000). Moreover, human capital is the intellect and intelligence of the company's actors (Bontis, 1998); furthermore, Bontis, Chua, and Richardson (2000) elaborated that human capital is the personal knowledge inventory of a company that is characterized by its actors which are attached to its bearer. Other scholars went into a more extended the definition to includes other features such as company's members' intelligence, believes, attitudes, qualifications, ingenuity, learning capacity, inspirational, intellectual agility, relations, risk-taking propensity, management initiatives abilities and proactivity (Youndt \& Snell, 2004; Wu, Melnyk, \& Calantone, 2007; Hsu \& Fang, 2009). Other scholar went into extending a bit more the definition to includes other elements such as that were mentioned before; human capital additional elements are such as emotional intelligence, flexibility, staff trustworthiness, actors' demographics, entrepreneurial spirits, vocational qualification and influencing behavior (Cricelli, Greco, \& Grimaldi, 2014). Other scholars have mentioned that human capital is not owned by the company either acquired as other capitals (e.g. equipment and technology) that are stored by the firm; thus human capital can depart from the company when the employees leave (Brymer, Molloy, \& Gilbert, 2014). Moreover, human capital is treated as one of the most important capitals for an organization and the variation level in human capital between firms has been linked to the competitive edge (Reed, Lubatkin, \& Srinivasan, 2006). Along the same line of thinking, variation among firms' business success is demonstrated by different factors, and human capital best illustrates the success (Vargas, Lloria, \& Roig-Dobón, 2016). Therefore, more resources must be spent to support the highly qualified human capital, inspired and valued when determining the organization's strategic direction (Ibarra Cisneros \& Hernandez-Perlines, 2018). For the purpose of this research, we have chosen to take the accentuated definition related to our field of intervention for human capital as per scholars who went into a more extended human capital definition to includes other attributes such as company's members' intelligence, believes, attitudes, qualifications, ingenuity, learning capacity, inspirational, intellectual agility, relations, risk-taking propensity, management initiatives abilities and proactivity (Youndt \& Snell, 2004; Wu, Melnyk, \& Calantone, 2007; Hsu \& Fang, 2009).

In order to clarify the human capital definition, we will provide concrete examples that are derived from the researcher's hands-on expertise in the field of retail e-commerce. The human capital of a retail e-commerce firm has to have many solid pillars; we will discuss a couple of them here and in the next section. We will discuss the human capital challenges in retail e-commerce. Training for specific asks in order to perform the job is very important. The human capital has to be always enhanced in this high pace environment. Online marketing skills in terms of increasing visibility and conversion to sales are very important. These techniques changes fast and not the same techniques work for different retail products even if they are related to the same line of products. Moreover, as mentioned earlier, retail e-commerce firms might be operating with a very small number of employees; hence, a single employee would have many different tasks on hands corresponding to different departments. From this, training on enhancing employees' capabilities and abilities to acquire and perform many different tasks and responsibilities is essentials. The human capital capability to communicate effectively, constructively, and on a timely basis is a very important pillar in a retail e-commerce company. Moreover, a major pillar in human capital is that the employees' traits to have a positive attitude and intellectual agility along with proactivity initiative.

\subsection{Human capital challenges in retail e-commerce}

The retail e-commerce industry is very fast-paced; changes happen very fast; therefore, the human capital of the firm has to have solid bedrock in order for the firm to thrive in this industry. We will tackle human capital challenges that retail e-commerce faces in their operation and explain their consequences on the operation. The below material is generated from the researcher's deep expertise in the industry.

The main business model operation for a retail e-commerce firm is to have specific enhanced and creative online marketing strategies and techniques that can evolve very rapidly to the fast-changing environment. Online retails trends change fast, online marketing, and media techniques change and evolve very fast. If the human capital pillar is not strong and agile enough to keep pace with the evolvement required in the industry, the company could see its product sales and sales velocity deteriorate very fast. In return, this leads to adding pressure on excess inventory or obsolete products on hand. In return, the cash flow and financial position of the company might be at risk. Therefore, a well-trained, capabilities, and creative agility of a retail e-commerce company's human capital would reduce the hidden costs from this part of this needed business operation.

Another pillar that needs to be strong in a retail e-commerce business is the ability and capability of the human capital in the company to effectively and clearly communicate through emails, phone, with all related stakeholders of the business. 
There are many challenges in nature of conducting business when ordering from a foreign country, where the language is an obstacle. Moreover, the in-house communication should be very fluid and clear and aligned with the communication process drafted in the firm, in order to reduce miscommunication and misunderstanding that could affect negatively on the company revenues and profits. Employees might meet face to face during a day or couple; moreover, customers' communication is seldom done by phone, mostly it is done by email, which the employee should be able efficiently to discuss, negotiate, and constructive feedback. Therefore, having employees' communication skills enhanced to meet the need of the industry is very important which would reduce hidden costs and operation to perform smoothly.

Furthermore, the human capital, the company's actors, should have the right attitude and influencing behavior that is in a match with this industry. For example, issues that are raised almost daily, the firm's actors' attitude and behavior should be constructive in order to find the best sustainable solution in this fast-paced environment that would reduce hidden costs of the business.

As mentioned earlier, retail e-commerce business could be operating with a very small number of employees who are changing many hats, in terms of tasks and functions throughout the day. Therefore, the human capital should have the capability of multitasking and comprehend new delegated tasks, in order to push the business operation forward smoothly with minimum hiccups and tasks left undone. This would lead not to affect negatively business profitability.

Another challenge for retail e-commerce firms is to have the necessary skills to creatively choose their product line up for launch and to find decent acquisitions that fit the overall objective and strategy of the firm. Product selection for launch is very important as it determines the survivability and profitability of the company. Given the fast pace environment trends of online shoppers changes drastically fast and competition on products increases very fast. And the same hold for the acquisition of other retail e-commerce firms. Therefore, solid human capital skills available in the company would very well counter these mentioned challenges and propel business profitability.

All the challenges described above in this section tackle human capital challenges and covers the critical issues that a retail e-commerce firm's faces because of a weak human capital. Hence, validation from the literature perspective of the sub-hypothesis "Enhancement of human capital improves retail e-commerce firm's performance" is presented below. The validation of the latter from a field material of the intervention research would be presented and discussed in the assessment of intervention and hypothesis validation.

This sub-hypothesis is linked to the following force idea: There is a lack of job-specific skills enhancement across the company. From this force idea, the first key idea is generated through the conducted research intervention which states: There is a needed skill enhancement for new acquisitions and product launch. From a literature point of view, this sub-hypothesis is validated as per the following: Main success factors for the development of new products. Several major success elements include, for example: 1) the company must have a high-quality new production process and design new customer orientation products; 2) the company must be in a position to define its new product strategy, including its objectives, targets, and areas of strategic focus (Hsu \& Fang, 2009). Moreover, Wang, Wang, and Liang (2014) concluded that good-use of human expertise, skills, and capabilities of employees have optimistic and substantive organizational results.

The second generated key idea is: There is a needed skill enhancement for the logistics operation. From a literature point of view, this sub-hypothesis is validated as per the following: Human capital development has a substantial effect on the performance of organizations. In a competitive business environment, the development of human capital is unquestionably important (Waseem, Loo-See, Adeel, \& Riaz, 2018). Furthermore, the important positive relationship between human capital and company performance is well documented (Bontis, Chua, \& Richardson, 2000).

The third generated key idea is: There is a need for competency enhancement for specific tasks in the company operation. From a literature point of view, this sub hypothesis is validated as per the following: Between human capital and organizational performance, there is a positive influence. The human capital enhancement will thus improve the organization's performance (Gogan, Artene, Sarca, \& Draghici, 2016). Moreover, to play a major role in an organization's performance, investment in training and skill enhancement is needed for the human capital or make use of the external job market (Youndt \& Snell, 2004).

\subsection{Socio-economic theory}

The socio-economic theory (SEAM) is a management theory that ties ingeniously the social aspect of enterprises and their economic development (Savall \& Zardet, 2004-2011). In addition, a combination of a company's qualitative, quantitative, and financial facets has been developed, built, and analyzed by the socio-economic theory (Savall \& Zardet, 2004-2011). The theory's goal is to change corporate behavior to diminish confrontation and hidden costs. Organizational mechanisms are, technically, agent variables in the development of dysfunctions. There is a continuous interaction between the organization's procedures and the employees' conduct. This behavior, which is important for the manufacture and distribution of goods and services, is also a cause of dysfunctions. The theory reflects, in terms of resources, behavior, and abilities, on hidden costs and human capacity. The theory is based on the socio-economic principle of maximizing the organizations' overall activities and profitability, and a broad enterprise base conducted and implemented over the years shows the tremendous value of its utility and use. A meta-analytical study strengthens the socio-economic approach, a theoretical method to bridge a major distance between management theory and practice (Buono \& Savall, 2015).

Everything matters and everybody has a chance to step forward (Savall \& Zardet, 2012). If SEAM is implemented correctly in an e-commerce sector, it 
will give the firm's online retail e-commerce enterprises a lasting strategic advantage and will improve their expedited adaptability on all fronts. Traditional management, according to Conbere and Heorhiadi (2011), concentrates on financial information, without taking into account the company's employee perspectives and position. The SEAM theory is threefold: it provides a creative structure for efficient organizational management, a method for implementing progress in metamorphosis within organizations, and a wider dispersal network made up of radically different individuals and institutions (Savall, 2003). In SEAM theory there are two main principles to be described briefly: hidden costs and human potential. In any enterprise, there are entrenched dysfunctions in its operation which convert into hidden costs and weakness in viable financial performance (Savall, 2003). Human potential is the central principle of socio-economic philosophy, where it is defined that each participant has unique actions, abilities, and competencies and SEAM's goal is to improve the institution's human potential. Management has to collaborate with stakeholders of the business to identify and turn the untapped potential towards concrete potential.

\section{RESEARCH METHODOLOGY}

The researched firm faces micro-level challenges from a lack of strong human capital, which impedes its overall growth performance. In the last decade, the retail e-commerce market and online shopping have expanded quite rapidly. Retail e-commerce revenue growth is projected to double marginally between 2019 and 2022 (Statista, 2020). The entry barrier to the e-commerce market is incredibly low. Henceforth, this market is now becoming increasingly crowded and very competitive. There are many new entrants releasing daily with the same product portfolio as the competition. These results in a considerable drop in profitability margins across the board, and the profits of companies are dropping, as sales are split among several local and foreign players.

This investigated firm encountered many micro-environmental challenges that slowed down its development. The firm's skills are not optimized as they lack in new online marketing techniques for different sales channels, which is giving way for the competition and ultimately lose sales. The firm's financial analysis is weak and not able to promote reasonable recommendations from the company financials. This is resulting in loss of potential sales and decrease margins. The company is using a deficient valuation technique when it comes to acquiring companies. This is resulting in huge cash flow pressure on the company financials and or loss of potential acquisition. The product selection skills need enhancement from the related department in order to increase the growth of the product portfolio and the company's profitability. The firm's logistics did not get much upgrade since operating from the big warehouse, this is using up more time than necessary for staff, taking longer time to process returns; this is resulting in profit reduction. Moreover, the weak interpersonal skills among the company players are affecting the operation flow and create deadlock which in returns impact sales and margins. In order to recapitulate the microenvironment of the firm does not have solid pillars in terms of a strong platform of human capital. The company's lack of communication skills, training in core new online marketing approaches, valuation, financial analysis, logistics, and warehouse management enhancement; This lack of strong human capital and its impact on the firm's growth has enticed the firm's management to embrace the research intervention.

The researcher proposed the qualimetrics methodology, which is the socio-economic management method developed by Savall (1974), and updated by Jean Moulin University Lyon III's ISEOR Research Center as a methodology of institutional development technique with quantifiable results in the qualitative, quantitative and financial aspect.

The current problem of this research intervention study is about the deficiency of the company's human capital that is hampering its growth progress. For this intervention study the research questions are as follows: How can the enhancement of human capital may help to improve the e-commerce firm's performance? How SEAM intervention could contribute to the performance enhancement of e-commerce firms?

The goal of this intervention research is to encourage a transition to competitive resilience within the enterprise in order to grow; and to induce efficient, creative operational-tactical capability by constantly improving firm capital. The socioeconomic management model that turns enterprise problem areas into opportunities, adopts critical strategic thought, encourages improvements within the organization, and effectively incorporates all of the company's players' involvement to maintain strong truthfulness and trustworthiness of the result.

In this research, the hypothesis describes the dynamics of intervention analysis and decodes the concept suggested in the empirical review into the systemic framework of the company as follows: "Enhancement of human capital improves retail ecommerce firm's performance".

In 1974 the Socio-Economic Institute of Companies and Organizations (ISEOR) was established by Professor Henri Savall. After then, several books have been published that help develop a comprehensive approach to research to find hidden costs and profit that represent expenses and benefits not expressed in the financial systems of the organization (Savall, 1974). Hence, this results in dysfunctions. Henri Savall has exposed that the dysfunctions and regulations are the cornerstones of hidden costs and accomplishments. Over the years, the socio-economic methodology has been developed by Professor Henri Savall and ISEOR team, equipped with strategies tailored to a specific context. Emerging techniques, capabilities, and knowledge are not forced but built in a way that complies with and contributes to the theory of action science collaboration using capacity-building approaches and procedures.

The socio-economic methodology implemented in this intervention research focuses on behavioral change and outcomes that are being examined as a consequence of the interplay among the intervenerresearcher and the firm's players within the 
company since they appear to occur concurrently and consecutively. That will result in an incorporated combination of qualitative, quantitative, and financial data (Savall, Zardet, Péron, \& Bonnet, 2012). This adopted socio-economic approach is labeled the qualimetrics method which is based on the tri-axial process: "the process of improvement, the innovative socio-economic management tools and the political and strategic decisions" (Cappelletti \& Baker, 2009; Savall Zardet, Péron, \& Bonnet, 2012). The descriptions of the Thrihedron axis phases can be seen in Figure 1 below. This methodology has been studied and applied in several organisations since 1974 in 34 countries around the world, across different industries and sectors (Buono \& Savall, 2007; Savall, 2003).

Figure 1. SEAM A, B \& C spiral axes

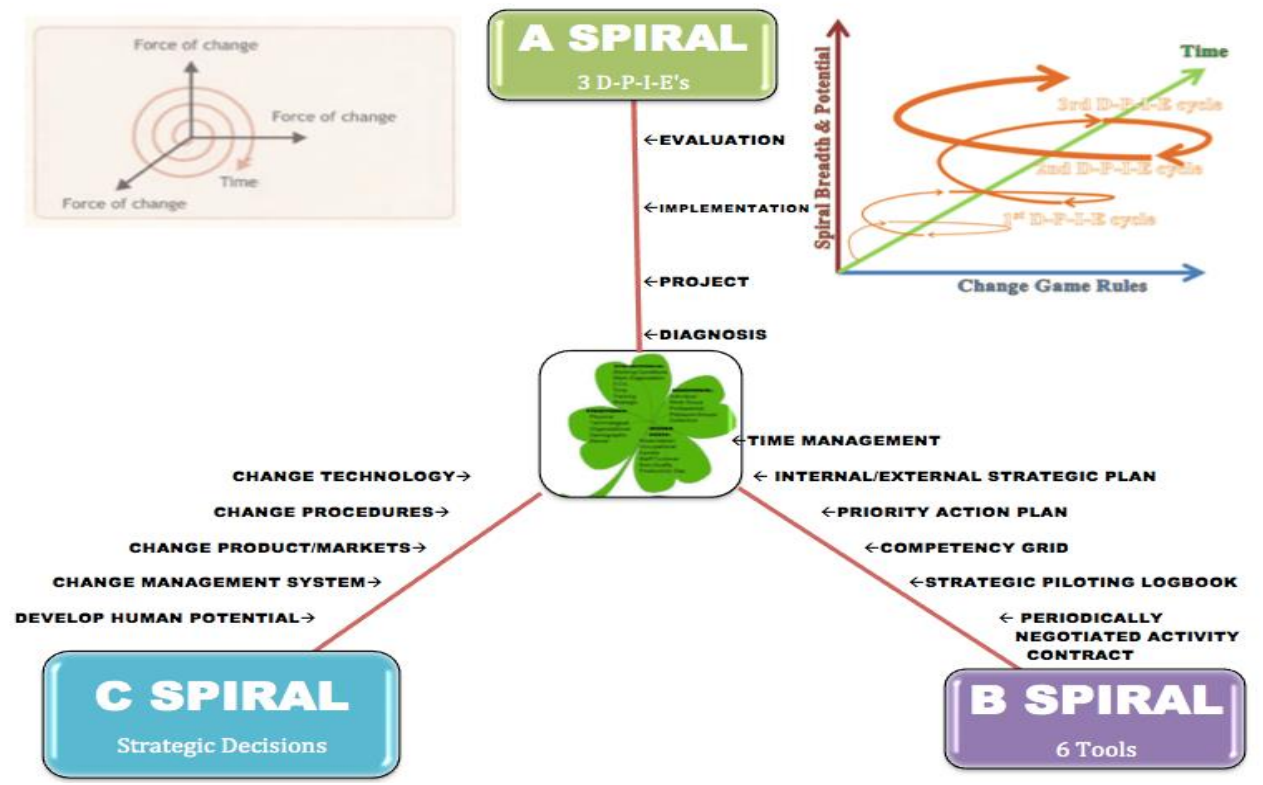

Source: Savall et al. (2012).

The negotiation process is a vital part of socio-economic intervention because the firm's general manager must well comprehend all the relevant intervention steps that are necessary. Furthermore, he would actively promote the initiative in all its stages until the intervention is completed.

Diagnostic process: During this diagnostic process the intervener must take several steps. The approach is implemented in the company from executives to front-line workers, covering all firm's actors. This stage starts with the compilation of business records, pertinent field observation, and semi-structured interviews with all firm's associated stakeholders. It is followed by hidden cost estimation, mirror effect, expert advice, and basket development.

Mirror effect: The mirror effect is a qualitative analysis focused on excerpts from actors in the organization, which helps them interpret their excerpts in a manner that validates, contradicts, enhances, or complicates them. The mirror effect is a summary of the semi-structured interview material with quotes from actors distributed aggregately and anonymously to all the participants in the corporation as a whole. It leads to open a lot of discussion and interpretation of dysfunctions, paving the door for a deeper understanding of how to repair them.

Expert advice: The expert advice reflects the generated key ideas of reported dysfunctions, aggregated insights, and the discussion about the mirror effect that illustrated the most cited dysfunctions that seemed to be the most distressing and harmful to the operation of the organization, and outlined in a very clear language. It is an extra degree of evaluation, above and beyond the data already gathered. The expert advice offers a confirmation method and contradictory statements on the cited dysfunctions of the organization's actors; hence, it is specific to the company (Savall \& Zardet, 2004-2011). The main ideas and purpose of the expert advice are to reconfigure the compiled key ideas to construct the baskets which will be embedded into the socio-economic projects. The subsequent two phases are then the implementation of socio-economic development projects preceded by an evaluation process.

Management tools: The socio-economic management tools entail enhancing primacy management activities, improved use of current expertise capabilities, increased visibility by piloting activities and dysfunction pointer measures, and hidden cost avoidance and enhanced anticipation of a mid- to long-term business climate transition (Conbere, Savall, \& Heorhiadi, 2015).

Strategic action plan: A short to long term masterplan for an enterprise is an internal and external strategic action plan. This approach represents the organization's target for the next 3-5 years and outlines the phases for the organizational strategy so that actors in the business can devise strategies for the accomplishment of the strategic objectives of the corporation (Savall, Zardet, \& 
Bonnet, 2008). The priority action plan is a six-month program, focused on the internal and external strategic action plan for enterprises. The approach offers a series of step-by-step measures to define the projects and methods with added value tasks needed to meet the goals of the company.

Self-assessment time management: Time management self-assessment process is a very valuable method for clarifying and determining how management is allocating and investing their energy and time on projects and assignments. The executive committee would be concentrated on assessing how time was spent by the management and how it was utilized in value-added activities. Managers will fill it up to five days in a row to reflect their usual truetime usage over regular working days.

Competency grid: The competencies grid highlights and illuminates the firm's current knowledge skills. Every manager uses this to assess the existing and needed skills in his unit, as well as what additional skills are needed to accomplish the corporate strategy. It entails day-to-day operations, growth activities, necessary capability attributes, and also the creation of new operations (Savall, Zardet, \& Bonnet, 2008).

Strategic piloting logbook: The piloting logbook assesses the effects of the change management process (Savall, Zardet, \& Bonnet, 2008).

Activity contracts: This tool is used by a company's employee and his direct supervisor, who jointly agrees and set common objectives and strategies that reflect corporate, departmental, and internal targets priorities.

Policy and strategic decision axis: The third axis is the policy and strategic decision axis focusing on the steps that should be made by the executive management team to facilitate the development and execution of enhancements in the management strategic agenda of the enterprise. The effect of the processes performed to reduce or remove dysfunctions helps to build support for the suggested structure of the development cycle implemented by the management tool axis. The socio-economic intervention helps the actors of the company speed up the policy and strategic decision-making process. It also challenges these same actors to be consistent in their choice (Savall, 2003).

\section{RESEARCH RESULTS}

The qualitative semi-structured interviews were performed for approximately 1 hour each in the first stage of diagnosis, with all members of the company separately. The second stage of the diagnostic interviews was to gather information, from the company's managers, by questioning for an hour and a half each of the following members to quantify the gathered dysfunctions cost: the two managing directors and the accounting/finance manager. The information gathering from the above-mentioned interviews helps the researcher to evaluate and better understand the perspectives of the participants in the organization, the challenges, and dysfunctions they encounter in their everyday operations and their consequences. Table 1 shows the representation of the personnel-mentioned dysfunctions and the number of conceptual key ideas generated and categorized by SEAM themes.
Table 1. Distribution of dysfunctions cited by personnel and the number of generating key ideas by themes

\begin{tabular}{|l|c|c|}
\hline \multicolumn{1}{|c|}{ Total number of dysfunction quotes } & \multicolumn{2}{c|}{$\mathbf{6 6}$} \\
\hline \multicolumn{1}{|c|}{ Distribution by them } & Nb & $\boldsymbol{\%}$ \\
\hline Work conditions & 15 & 23 \\
\hline Work organization & 17 & 26 \\
\hline Communication-coordination-cooperation & 10 & 15 \\
\hline Time management & 8 & 12 \\
\hline Integrated training & 12 & 18 \\
\hline Strategic implementation & 4 & 6 \\
\hline
\end{tabular}

The expert advice which addresses many of the recognized dysfunctions during the diagnostic process produced eleven baskets, which are represented by the socio-economic improvement projects. In order to determine the baskets to pursue first (priority projects), it took the steering committee a few days to assess and review it internally, the baskets were presented and debated thoroughly, and accepted by the steering committee consisting of both managing directors. The eleven socio-economic improvement projects which were created are shown in Table 2. Afterward, the stage of the project group took place, followed by stages of implementation and evaluation.

Table 2. Eleven generated baskets

\begin{tabular}{|l|}
\hline \multicolumn{1}{c|}{ Expert advice } \\
\hline $\begin{array}{l}\text { Define new process for new products and company } \\
\text { acquisition }\end{array}$ \\
\hline $\begin{array}{l}\text { Align the annual budget with the business development } \\
\text { department }\end{array}$ \\
\hline $\begin{array}{l}\text { Align the annual budget and cashflow position with the } \\
\text { growth strategy }\end{array}$ \\
\hline Effective inventory software infrastructures \\
\hline Effective financial software infrastructures \\
\hline Effective job descriptions and department's tasks \\
\hline Effective operation processes \\
\hline Effective interdepartmental communication \\
\hline Competency integrated training programs \\
\hline External stakeholder relationship enhancement \\
\hline Internal stakeholder relationship enhancement \\
\hline
\end{tabular}

The second stage of the intervention diagnostic phase is the quantitative process. This is to gather estimated average quantitative data from the relevant managers, based on dysfunctions identified by all the players of the business. We calculated the cost of hidden in this phase. They will quantify the costs associated with the known dysfunctions so that the organization's management can see and assess the financial magnitude of the costs connected with the recognized dysfunctions (Savall \& Zardet, 1992). SEAM diagnosis has quite a simple process to adopt, and the findings are typically irrefutable, as demonstrated by a mixture of qualitative and quantitative evidence (Buono \& Savall, 2007). The hidden costs analysis aims to clarify and shed light on the corporation's documented economic effect of dysfunctions; in fact, it is to entice the company's workers to accept developmental evolution.

The procedure and calculation of the hourly contribution to value-added on variable cost (HCVAVC) are demonstrated in Table 3 below. The researched organization has an HCVAVC of $\$ 81.98$ which signifies the economic added value of each working paid hour per employee. 
Annual sales - Variable cost $=$ Margin on Variable cost

HCVAVC $=$

Margin on Variable cost/ Total work hours

Table 3. The calculation of HCVAVC

\begin{tabular}{|l|c|}
\hline \multicolumn{2}{|c|}{$\begin{array}{c}\text { Calculation of "HCVAVC" hourly contribution to value- } \\
\text { added on variable cost }\end{array}$} \\
\hline & $\mathbf{2 0 1 7}$ \\
\hline Revenues & $\$ 1,644,160.32$ \\
\hline Variable cost & $\$ 1,097,835.27$ \\
\hline Margin on variable cost “VAVC" & $\$ 546,325.05$ \\
\hline Annual work hours for all actors & 6664 \\
\hline Total work hours & 6664 \\
\hline HCVAVC & $\$ 81.98$ \\
\hline
\end{tabular}

The hidden cost study was performed with relevant managers in each unit to determine the effect of the highlighted dysfunctions in six elements and five measures for economic impact. The hidden cost approach is a valuable technique for assessing and making the financial cost of the dysfunctions clear so that administrators can properly understand the severity of the condition. Supervisors who have a clear knowledge of their respective unit' operations have analyzed and conservatively calculated the estimated hidden costs. On average, the hidden costs were $\$ 35,000$ per employee per year.

The evaluation interviews performed by interviewing each shareholder for an hour to discuss the implications of the intervention performed and the socio-economic projects carried out. This was conducted approximately twelve months after the intervention and the socio-economic projected implemented and concluded. The researcher has described the findings of this assessment below.

Marketing skills enhancement: The primary shareholder has shifted his time spent from none value tasks to value tasks, which gave him more time to enhance his online marketing skills; in addition, he made it a daily routine to better understand and acquire new online advertising strategies. This paved the way to enhance and to implement efficient advertising strategies that correspond to the business needs. Initially, when he started the skill enhancement and the implementation, he overspent on advertising, but with a bit of time and practice, the primary shareholder was able to calibrate the advertising dollar spent and made it more efficient. Moreover, he started the steps toward studying and researching the possibility of expanding his product line sales to brick and motor stores. He already started a discussion with potential sales people experienced in this field, which represents a step forward in the company's long term vision to penetrate that segment. This is remedial for the dysfunction field quotes "There are some training required for job specifics". The overall benefits of this implemented socio-economic are calculated to approximately $\$ 23,000$ per year. This validates that an improvement of the human capital will lead to an improved retail e-commerce firm's performance.

Product pricing skills enhancement: The better pricing strategy goes hand in hand with the marketing skill enhancement that the primary shareholder has performed. He self-trained and experimented with a couple of strategies and figure out an efficient strategy that works well for the existing business environment. Instead of reducing price and make it impossible to raise it again, the strategy is to offer at a breakeven an additional complementary low priced product. This is remedial for the dysfunction field quotes "There are some training required for job specifics". The overall benefits of this implemented socio-economic are calculated to approximately $\$ 12,000$ per year. This validates that an improvement of the human capital will lead to an improved retail e-commerce firm's performance.

Enhancement process of new product selection: The primary shareholder has drafted his findings of the last couple of years of new product selection, in order to define what went well and didn't, so to enhance his department skills and the process. He redesigned the required features, market segmentation, dollar value price, competition, suppliers, and manufacturers just to mention some of the parameters that were drafted based on his newly acquired skills. This has led them to choose two existing products for 2019 to lunch on different sales channels in order to support the new processor to readjust it. This is remedial for the dysfunction field quotes "There are some training required for job specifics". The overall benefits of this implemented socio-economic are calculated to approximately $\$ 25,000$ per year. This validates that an improvement of the human capital will lead to an improved retail e-commerce firm's performance.

Logistics management skills enhancement: The second shareholder enhanced his logistics skills and was able to optimize the carrier choice, method of shipment choice (containers, pallets or parcels, expedited or regular), procedure, and system; hence, he reduced the significantly the overseas and domestic shipping cost. This is remedial for the dysfunction field quotes "There is a need for training on the logistic management optimization". The overall benefits of this implemented socio-economic are calculated to approximately $\$ 17,000$ per year. This validates that an improvement of the human capital will lead to an improved retail e-commerce firm's performance.

\section{CONCLUSION}

This research encompassed a number of fronts to provide a concise study review. The field challenges and the research questions were identified by this intervention research and are consistent: The problem statement for this intervention study is that the organization is facing challenges human capital basis that is hindering its development. The research questions for this intervention research are as follows: How can the enhancement of human capital help to improve the e-commerce firm's performance? How SEAM intervention could contribute to the performance enhancement of e-commerce firms? The core hypothesis was subsequently formulated based on the knowledge collected from the analysis, which is defined as: "Enhancement of human capital improves retail e-commerce firm's performance". The researcher then positioned the literature to include the human capital and the well-defined and described socio-economic theory. The last two parts of this paper discuss the importance of impact evidence to optimize the positive effect of human capital on corporate growth.

The first research problem: "How can the enhancement of human capital help to improve the e- 
commerce firm's performance?" It was validated and verified from the literature standpoint and the findings and discussion presented in this intervention research paper. Via the improvement priority projects carried out in this socio-economic approach, human capital development via connectivity integration, seamless flow of knowledge exchange between internal and external stakeholders, socio-economic priority projects have strengthened the organization's human capital. The effects of the adoption of the enhanced human capital had a net benefit of $\$ 77,000$ a year for the organization.

The purpose of this research is to encourage the transformation within the enterprise to competitive agility in order to thrive; and to bring an active, innovative intellect into the continuous development of the resources of the business. The socio-economic management model, which turns the shortcomings of the company into opportunities, stresses constructive structural research, promotes change inside the enterprise, and value sincere participation from all stakeholders, which requires absolute truthfulness and success liability. In addition, the research sheds light on the notion of hidden costs in e-commerce companies and encourages approaches to reduce it and turn lowvalue-added activities into added value by growing the sustainability performance of the organizations. The study outcome validates the investigated second research question: "How SEAM intervention could contribute to the performance enhancement of e-commerce firms?" The socio-economic intervention has triggered changes in the company by the players themselves. The project group phase that the team underwent was enhanced in the way they execute operational tasks, and the level of teamwork, communication, and collaboration across stakeholders at all corporate levels was significantly improved. Therefore, it improves interdepartmental project productivity and greatly decreases operating errors. The mirror effect has evoked a lot of constructive conversation between actors to discuss the dysfunctions with the eventual aim of seeking solutions and proposals for them. This generates a lot of coordination between actors with common goals to maximize the efficiency and output of the company.

The significance of this intervention research is that by improving human capital it positively contributes significantly to the performance of a retail e-commerce company that affects unique qualitative and quantitative metrics created for this research that previous scholars have not investigated.

This research paves the way for future studies based on the impact of the variables of intellectual capital on the competitiveness and operations of ecommerce firms. The case study approach is apparently one of the limitations of this contribution. Another limitation is the availability of data on e-commerce companies in the Middle East.

Future research could examine the proposed concept of this paper in various configurations within the e-commerce sector, using a bigger sample size. Such examinations may help to explain the related factors (such as competitive enhancement and operational effectiveness) that could affect the interconnections suggested in this research.

\section{REFERENCES}

1. Bontis, N. (1996). Intellectual capital: An exploratory study that develops measures and models. Paper presented at the 17th McMaster Business Conference, Richard Ivey School of Business.

2. Bontis, N. (1998). Intellectual capital: An exploratory study that develops measures and models. Management Decision, 36(2), 63-76. https://doi.org/10.1108/00251749810204142

3. Bontis, N. (2001). Assessing knowledge assets: A review of the models used to measure intellectual capital. International Journal of Management Reviews, 3(1), 41-60. https://doi.org/10.1111/1468-2370.00053

4. Bontis, N., Chua, W., \& Richardson, S. (2000). Intellectual capital and business performance in Malaysia. Journal of Intellectual Capital, 1(1), 85-100. https://doi.org/10.1108/14691930010324188

5. Braendle, U., Farah, A., \& Balian, P. (2017). Corporate governance, intellectual capital and performance: Evidence from the public sector in the GCC. Risk Governance and Control: Financial Markets \& Institutions, 7(4), 23- 29. https://doi.org/10.22495/rgc7i4art3

6. Brooking, A. (1996). Intellectual capital: Core asset for the third millennium. London, UK: International Thomson Business Press.

7. Bruce, G. M., \& Daly, L. (2010). Innovative process in e-commerce fashion supply chains. In T. C. Cheng, \& T.-M. Choi (Eds.), Innovative quick response programs in logistics and supply chain management (pp. 227-241). Springer Berlin, Heidelberg. https://doi.org/10.1007/978-3-642-04313-0_11

8. Brugnoli, G., Mangiaracina, R., \& Perego, A. (2009). The e-commerce customer journey: A model to assess and compare the user experience of the e-commerce websites. Journal of Internet Banking and Commerce, 14(3), 1-11. Retrieved from http://www.icommercecentral.com/open-access/the-ecommerce-customer-journey-amodel-to-assess-and-compare-the-user-experience-of-the-ecommerce-websites.php?aid=38368

9. Brymer, R. A., Molloy, J. C., \& Gilbert, B. A. (2014). Human capital pipelines: Competitive implications of repeated interorganizational hiring. Journal of Management, 40(2), 483-508. https://doi.org/10.1177/0149206313516797

10. Buono, A., \& Savall, H. (2007). Socio-economic interventions in organizations. Charlotte, NC: Information Age Publishing Inc.

11. Buono, A., \& Savall, H. (2015). The socio-economic approach to management revisited. Charlotte, NC: Information Age Publishing Inc.

12. Cappelletti, L. G., \& Baker, C. R. (2010). Developing human capital through a pragmatic oriented action research project: A French case study. Action Research, 8(2), 211-232. https://doi.org/10.1177/1476750309349976

13. Conbere, J., \& Heorhiadi, A. (2011). Socio-economic approach to management. OD PRACTITIONER, 43(1), 6-10. Retrieved from https://pdfs.semanticscholar.org/687e/00c4a2db4f4822a22e90f592ac50d7654c86.pdf

14. Conbere, J., Savall, H., \& Heorhiadi, A. (2015). Decoding the socio-economic approach to management: Results of the Second SEAM Conference in the United States. Charlotte, NC: Information Age Publishing Inc.

15. Cricelli, L., Greco, M., \& Grimaldi, M. (2014). An overall index of intellectual capital. Management Research Review, 37(10), 880-901. https://doi.org/10.1108/MRR-04-2013-0088 
16. Dzinkowski, R. (2000). The measurement and management of intellectual capital: An introduction. Management Accounting, 78(2), 32-36.

17. Edvinsson, L., \& Malone, M. (1997). Intellectual capital: Realizing your company's true value by finding its hidden brainpower. New York, NY: Harper Collins Publishers, Inc.

18. Ghezzi, A., Mangiaracina, R., \& Perego, A. (2012). Shaping the e-commerce logistics strategy: A decision framework. International Journal of Engineering Business Management, 4(13), 1-13. https://doi.org/10.5772/51647

19. Gogan, L. M., Artene, A., Sarca, I., \& Draghici, A. (2016). The impact of intellectual capital on organizational performance. Procedia - Social and Behavioral Sciences, 221, $194-202$. https://doi.org/10.1016/j.sbspro.2016.05.106

20. Hsu, Y.-H., \& Fang, W. (2009). Intellectual capital and new product development performance: The mediating role of organizational learning capability. Technological Forecasting and Social Change, 76(5), 664-677. https://doi.org/10.1016/j.techfore.2008.03.012

21. Ibarra Cisneros, M. A., \& Hernandez-Perlines, F. (2018). Intellectual capital and organization performance in the manufacturing sector of Mexico. Management Decision, 56(8), 1818-1834. https://doi.org/10.1108/MD-10-2017-0946

22. MacCarthy, J., \& Amoasi-Andoh, R. (2020). Could the Altman Z-score model detect the financial distress in Ghana? Multivariate discriminant analysis. Corporate Governance and Sustainability Review, 4(2), 8-19. https://doi.org/10.22495/cgsrv4i2p1

23. Oppong, S. A., Yen, D. C., \& Merhout, J. W. (2005). A new strategy for harnessing knowledge management in ecommerce. Technology in Society, 27(3), 413-435. https://doi.org/10.1016/j.techsoc.2005.04.009

24. Park, E. J., Kim, E. Y., Funches, V. M., \& Foxx, W. (2012). Apparel product attributes, web browsing, and eimpulse buying on shopping websites. Journal of Business Research, 65(11), 1583-1589. https://doi.org/10.1016/j.jbusres.2011.02.043

25. Ranjan, R. K., Siddiqui, S. A., Thapar, N., \& Chauhan, S. S. (2020). E-commerce and portfolio allocations: A study on the Indian life insurance customers. Corporate \& Business Strategy Review, 1(1), 36-46. https://doi.org/10.22495/cbsrvlilart4

26. Reed K. K., Lubatkin, M., \& Srinivasan, N. (2006). Proposing and testing an intellectual capital based view of the firm. Journal of Management Studies, 43(4), 867-893 https://doi.org/10.1111/j.1467-6486.2006.00614.x

27. Roos, G., \& Roos, J. (1997). Measuring your company's intellectual performance. Long Range Planning, 30(3), 413-426. https://doi.org/10.1016/S0024-6301(97)00022-8

28. Savall, H. (1974-1975). Enrichir le travail humain dans les entreprises et les organisations [Work and people: An economic evaluation of job enrichment]. Paris, France: Dunod

29. Savall, H. (2003). An updated presentation of the socio-economic management model. Journal of Organizational Change Management, 16(1), 33-48. https://doi.org/10.1108/09534810310459756

30. Savall, H., \& Zardet, V. (1992). Le nouveau contrôle de gestion: Méthode des coûts-performances cachés [New management control: The hidden cost-performance method]. Paris, France: Eyrolles-Éditions Comptables Malesherbes.

31. Savall, H., \& Zardet, V. (2004-2011). The qualimetrics approach: Observing the complex object. Charlotte, NC: Information Age Publishing Inc.

32. Savall, H., \& Zardet, V. (2012). Les entreprises familiales création, succession, gouvernance et management. Paris, France: Economica

33. Savall, H., Zardet, V., \& Bonnet, M. (2008). Releasing the untapped potential of enterprises through socioeconomic management. Retrieved from http://ns3040652.ip-164-132163.eu/SiteIseor/ISEOR_ANGLAIS/pdf/publications-anglaises/Book_Eng_chap5-web.pdf

34. Savall, H., Zardet, V., Péron, M., \& Bonnet, M. (2012). Possible contributions of qualimetrics interventionresearch methodology to action research. International Journal of Action Research, 8(1), 102-130. Retrieved from https://www.semanticscholar.org/paper/Possible-Contributions-of-Qualimetrics-Methodology-SavallZardet/95934b40b896d567c2e99572393a6c3087c68f72?p2df

35. Statista. (2020). Global retail e-commerce market size 2014-2023. Retrieved from https://www.statista.com/statistics/379046/worldwide-retail-e-commerce-sales/

36. Stewart, T. A. (1997). Intellectual capital: The new wealth of organizations. New York, NY: Doubleday.

37. Subramaniam, M., \& Youndt, M. A. (2005). The influence of intellectual capital on the types of innovative capabilities. Academy of Management Journal, 48(3), 450-463. https://doi.org/10.5465/amj.2005.17407911

38. Sullivan, P., \& Edvinsson, L. (1996). A model for managing intellectual capital. In R. Parr, \& P. Sullivan (Eds.), Technology licensing: Corporate strategies for maximizing value (pp.249-260). New York: NY. John Wiley \& Sons.

39. Tian, L., Vakharia, A., Tan, Y., \& Xu, Y. (2018). Marketplace, reseller, or hybrid: Strategic analysis of an emerging e-commerce model. Production and Operations Management, 27(8), 1595-1610. https://doi.org/10.1111/poms.12885

40. Vargas, N., Lloria, M. B., \& Roig-Dobón, S. (2016). Main drivers of human capital, learning and performance. The Journal of Technology Transfer, 41(5), 961-978. https://doi.org/10.1007/s10961-016-9483-6

41. Wang, W.-Y., \& Chang, C. (2005). Intellectual capital and performance in causal models: Evidence from the information technology industry in Taiwan. Journal of Intellectual Capital, 6(2), 222-236. https://doi.org/10.1108/14691930510592816

42. Wang, Z., Wang, N., \& Liang, H. (2014). Knowledge sharing, intellectual capital, and firm performance. Management decision, 52(2), 230-258. https://doi.org/10.1108/MD-02-2013-0064

43. Waseem, B., Beh, L.-S., Adeel, A., \& Riaz, A. (2018). Impact of intellectual capital on innovation capability and organizational performance: An empirical investigation. Serbian Journal of Management, 13(2), 365-379. https://doi.org/10.5937/sjm13-16997

44. Wu, S. J., Melnyk, S. A., \& Calantone, R. J. (2007). Assessing the core resources in the environmental management system from the resource perspective and the contingency perspective. IEEE Transactions on Engineering Management, 55(2), 304-315. https://doi.org/10.1109/TEM.2008.919727

45. Youndt, M. A., \& Snell, S. A. (2004). Human resource configurations, intellectual capital, and organizational performance. Journal of Managerial Issues, 16(3), $337-360 . \quad$ Retrieved from https://www.jstor.org/stable/40604485?seq=1

46. Youndt, M. A., Subramaniam, M., \& Snell, S. A. (2004). Intellectual capital profiles: An examination of investments and returns. Journal of Management Studies, 41(2), 335-362. https://doi.org/10.1111/j.14676486.2004.00435.x 